\title{
Voldsspiralen har snurret stadig hurtigere fra 2009
}

Vibeke Sperling

Ny rapport om volden i Nordkaukasus påviser dramatisk stigning i 2009. Og nye beviser imod Kadyrov rejser spørgsmålet, om Moskva kan blive parat til at skille sig af med ham

Borgere i Tjetjenien fik en ny national fridag i år, 16. april, årsdagen for Kremls officielle afslutning på antiterroroperationen i landet. Det vakte dengang forhåbninger om, at afslutning på et årtis russisk 'krig imod terror' i regionen ville bringe bedre vilkår for menneskerettighederne. Men sådan gik det jo ikke.

Og terrorangrebene i Moskvas metro i slutningen af marts viste den forværrede sikkerhedssituation ikke bare i Tjetjenien, men i hele Nordkaukasus.

De syv såkaldt autonome russiske republikker i Nordkaukasus bliver stadig mere islamiserede, når man drager fra vest til øst igennem Adygeja, Karatjevo-Tjerkessien, Kabardinien-Balkarien, Nordossetien, Ingusjetien, Tjetjenien og Dagestan.

Nordossetien er en kristen $\varnothing \mathrm{i}$ et islamisk hav, da flertallet af nordosseter- ne er russisk ortodokse. Eneste republik, som hidtil er holdt næsten uden for voldsspiralen, er Adygeja.

Året, hvor Kreml erklærede antiterroroperationerne for slut i Tjetjenien, steg volden markant i hele Nordkaukasus. Det har bl.a. Center for Strategic and International Studies, CSIS, påvist i rapporten: Violence in North Caucasus. 2009: A bloody Year.

Der var tale om 1.100 blodige sammenstød i 2009 sammenlignet med 586 i 2008. Dødsofrene sidste år var 916, mens 2008 krævede 586 døsofre. En tredjedel af blodighederne i regionen skete i Ingusjetien, mens Tjetjenien stod for hovedparten af den firedobling af selvmordsangreb, som skete i regionen i 2009.

Ingusjetien stod for den største stigning i volden, fulgt af Dagestan, Tjetjenien på tredjepladsen og Ka- 
bardinien-Balkarien og Nordossetien på fjerde- og femtepladsen.

Dagestan opfører sig stadig mere som en trykkoger, hvor klankrige er intensiveret af den voksende islamiske fundamentalisme og stadig større fremmedgørelse i befolkningen.

Mens Moskva fremhæver, at det igennem præsident Ramsan Kadyrov har opnået større kontrol med Tjetjenien, så er Moskvas tab af kontrol tydeligst i Dagestan, hvor militante konkurrerer med klaner om republikkens ressourcer.

"Den værste hovedpine med Tjetjenien er en stærk leder, som er helt ukontrollabel for Moskva, men han har i det mindste styr på tingene", siger Pavel Bajev, forsker ved International Peace Research Institute i Oslo. "I Dagestan er problemet manglen på kontrol, som skaber vold af en anden slags, som er stærkere og stærkere og krydret med islamisk fundamentalisme. Der er ingen form for orden, og kun fundamentalisterne kan fremstå som ærlige mænd".

Fundamentalisterne har iværksat moralsk oprustning med angreb på bordeller og på kvinder, som de mener går for uislamisk klædt.

Dagestan med en pragtfuld kystlinje ud til Det Kaspiske Hav havde alle muligheder for blomstrende turisme, men oligarker har snuppet de bedste grunde til private sommerhuse, og mindre bemidlede lokale klager over, at strandene er for beskidte og misrøgtede til at nyde. Og når det gælder turister udefra, siger hovedstaden Makhatskalas borgmester, Said Amirov: "Vi kan ikke udvikle turisme, når vi har mord hver dag”. Amirov er lænket til en rullestol efter et mordforsøg.

I februar 2010 indsatte præsident Medvedev en ny præsident i Dagestan. Den afgåede Mukhu Alijev skabte i starten store forhåbninger $\mathrm{i}$ befolkningen om, at der ville blive gjort noget ved den bundløse korruption. Alijev var kendt som en af de få politikere, der ikke modtog bestikkelse, og han blev rost for at bo i en beskeden treværelsers lejlighed. Men Alijev viste sig for svag eller korruptionen for massiv. I 2009 døde over 300 dagestanske borgere under voldelige angreb, eller de blev myrdet af rivaler.

På 65 årsdagen for sejren i Anden Verdenskrig 9. maj skete adskillige eksplosioner og selvmordsangreb i Dagestan, Kabardinien-Balkarien og Tjetjenien.

Det kunne kaldes helt normalt for regionen, men med en lille forskel. Efter et bombeangreb imod højtstående embedsmænd 1. maj i Karbardinien-Balkariens hovedstad Naltjik, forsikrede lokale og centrale myndigheder, at sikkerheden ville blive garanteret for den store fest 9 . maj. Men det hindrede ikke angreb på tværs af Nordkaukasus.

"Russiske sikkerhedsstyrker og deres lokale allierede er ude af stand til at garantere sikkerhed selv en en- 
kelt dag, hvor angreb var ventet. Det forklarer også, hvorfor topfolk som ministerpræsident Vladimir Putin og præsident Dmitrij Medvedev uvægerlig ankommer til regionen uden at være anmeldt forud", skriver Valerij Dsutsev.

(www.jamestown.org)

I Dagestan alene var der bombeangreb 7., 8. og 9. maj. Første dag blev en civil dræbt af en bombe på jernbanestationen, dagen efter blev en jernbanelinje bombet i stykker i hovedstaden, og 9. maj sprang to bomber, en i Kaspijsk og en i en forstad til Makhatjkala, der dræbte et ukendt antal mennesker.

"Terrorismen i Nordkaukasus bliver værre, trods styrkelsen af regeringens økonomiske, militære og samfundspolitiske indgriben i regionen", sagde Levon Batijev, vicedirektør for den sydlige afdeling af Ruslands Videnskabernes Akademi på en pressekonference. (Interfax 12.05.10)

Mens volden har bredt sig geografisk selv ind i Stavropol regionen uden for de nordkaukasiske republikker, lider myndighedernes modaktioner stadig af mangel på sammenhæng og koordinering, ifølge Batijev.

I Kabardinien-Balkarien tilskrives den øgede aktivitet fra militante, at organisationen Jarmuk Jamaat fik ny leder. Den tidligere leder, Anzor Astemirov, blev 27. marts i år lokket i baghold og dræbt af FSB. Nogle har kaldt terrorangrebet i Moskvas metro to dage efter for et hævnangreb, men det er næppe sandsynligt, da angrebene i metroen virkede nøje planlagt.

Det hører nu til dagens orden, at mobile militante skyder på politiets patruljevogne, når natten falder på i republikken. Det tyder på styrkelse af Jarmuk Jamaat og dens opstigning til rækkerne af Jamaat-bevægelser i Dagestan og Ingusjetien.

Kabardinien-Balkariens Jarmuk Jamaat blev skabt i 2004, hvor den erklærede hellig krig imod Rusland og indledte de første angreb på lokale myndigheder. I oktober 2005 rettede gruppen et massivt angreb på sikkerhedsstyrkerne, hvor over 100 blev dræbt i Naltjik.

\section{Europarådets værste region}

I slutningen af maj udsendte Europarådet et resolutionsforslag om situationen i Nordkaukasus. Heri hedder, at situationen i regionen, især i Tjetjenien, Ingusjetien og Dagestan, nu er "den mest alvorlige og vanskelige", når det gælder beskyttelse af menneskerettigheder i hele det geografiske område, som Europarådet overvåger. Konklusionen drages på grundlag af en rapport fra det schweiziske medlem Dick Marty.

Resolutionen beskriver situationen i Tjetjenien som præget af alt gennemtrængende frygt, konstante forsvindinger af regimets modstandere og menneskerettighedsaktivister. Retssystemet gør "simpelthen 
ingenting imod sikkerhedsstyrkernes forbrydelser". Og det sker under en skændig personkult. I Ingusjetien konstaterede Europarådet "et alarmerende opsving i vold siden 2009" og nye udbrud af terror i Dagestan mødes af "svar fra politiet på basis af ulovlige og kontraproduktive metoder".

Resolutionsforslaget opfordrer russiske centrale og regionale myndigheder til at bekæmpe terrorisme "med instrumenter, som en retsstat kræver" og søge forklaringen på radikaliseringen og den stigende indflydelse af religiøs ekstremisme. Myndigheder skal retsforfølge "alle skyldige i vold imod menneskerettigheder i overensstemmelse med loven", herunder medlemmer af sikkerhedsstyrkerne og de skal samarbejde tæt med menneskerettighedsorganisationer samt "beskytte deres stabsmedlemmer effektivt imod mulige repressalier".

I forbindelse med Den Europæiske Menneskerettighedsdomstols kendelser imod alvorlige og gentagne krænkelser af fundamentale rettigheder velkommer Europarådets resolutionsforslag "særlige bestræbelser fra russiske myndigheder", men konstaterer, at "mærkbare resultatet stadig lader vente på sig".

Parlamentarikerne opfordrer andre medlemslande til at samarbejde med Rusland i terrorbekæmpelse, garantere "effektiv beskyttelse af tjetjenere i eksil", som de har modtaget på deres territorium og "vurdere med den størst mulige omhyggelighed udleveringskrav imod kaukasiere i eksil, som kan risikere at blive dræbt, underlagt tortur eller unfair retssager".

Europarådets parlamentariske forsamling drøfter resolutionen på sin sommersamling, 21-25 juni 2010.

\section{Nordkaukasus langt fra Moskva}

Da terroren vendte tilbage til Moskva efter seks års pause i hovedstaden, tilskrev mange det, at terroristerne ville ryste moskovitterne ud af en falsk følelse af sikkerhed.

Men efterhånden som tiden går, frygter flere kommentatorer, at tendensen til helst at ville glemme Nordkaukasus blot vender tilbage. Som Sergej Markedonov, Kaukasusekspert ved Institut for Politiske og Militære Analyser i Moskva har udtrykt det i et interview til Moscow Times: "Kaukasus er langt væk, i det fjerne derovre et eller andet sted, så rager det ikke os, men det gør eksplosioner i Moskva selvfølgelig”.

Mens Ruslands forsøger at koordinere svar på de seneste eksplosioner, frygter menneskeretsorganisationen Memorial og politiske kommentatorer som Dmitrij Trenin, Aleksej Malasjenko (Se hans artikel først i dette tema) og Pavel Bajev, at præsident Dmitrij Medvedev er parat til at godkende nye forsøg på at bremse volden med vold. Også selv om Medvedev har vist en vis forståelse for, at indsats for at rette op på den kata- 
strofale sociale situation i Nordkaukasus kan gøre mere.

Men magtfulde kræfter som ministerpræsident Vladimir Putin har presset på, og der synes at være tendens i hans parti Forenet Rusland til at mene, at man kan udslette terrorister endegyldigt med en lidt mere effektiv udnyttelse af sikkerhedsstyrkerne. Kort efter de seneste selvmordsbomber i metroen sagde Boris Gryslov, parlamentets formand og ledende medlem af Forenet Rusland, til nyhedsbureauet RIA Novosti: "Det er alt for sent at rehabilitere dem". Ingen vil vel græde over, at terrorister bliver sat ud af spillet, men nu som før vil det sandsynligvis ramme langt flere uskyldige.

Andrej Soldatov, redaktør af internetavisen Agentura.ru, der fokuserer på sikkerhedsspørgsmål, fremhæver, at de russiske sikkerhedsstyrker koncentrerer sig om at forhindre storstilede aktioner og ikke er forberedt på nye fænomener fra Nordkaukasus.

"Vi ser en ny modus operandi, hvor små terrorceller på tre til fem mand udfører sabotageaktioner. Men vore sikkerhedsstyrker har militariseret problemet og er ikke gearet til mindre trusler som denne. Den hovedansvarlige for antiterror er indenrigsministeriet, som i praksis styrer en veritabel hær, som på ingen måde var forberedt på det, som måtte komme".

Soldatov beskriver den nye fare således: "Vi ser kræfter i Nordkauka- sus smelte sammen. De er ikke interesseret i lokal nationalisme eller separatisme, men ser sig selv som i krig imod Rusland. Indtil for nylig drog de mest eventyrlystne til Tjetjenien, nu spreder de sig langt mere".

Lederen af Ruslands ortodokse kirke, patriark Kirill, har manet til besindighed og advaret imod, at terrorangrebene øger spændingerne imellem Ruslands kristne flertal og det store muslimske mindretal.

Medvedev kunne bruge sin magt til at udpege regionale leder til at ændre de nordkaukasiske regimer fra toppen. I slutningen af april udnævnte han Nordossetiens præsident, Taimuras Mamsurov, til en anden periode. Han blev oprindelig udnævnt af Vladimir Putin. Mamsurov er medlem af det øverste råd i regeringspartiet Forenet Rusland, så ham turde Medvedev nok ikke fjerne.

\section{Går Kadyrov altid fri?}

Og hvad med Ramsan Kadyrov, som Medvedev nemt kunne handle imod på grund af hans beviste omfattende korruption. Men på papiret er Kadyrov en af Ruslands fattigste regionale ledere, hvis ikke den fattigste. Han bor officielt i en 36 kvadratmeter lille lejlighed og har ingen biler. I 2006 forærede to forretningsmænd Kadyrov flere biler, herunder en Ferrari, en Lexus og en Lamborghini, som der er taget flere billeder af foran familiens hus. Men Kady- 
rovs talsmand sagde til avisen Vedomost $i$ i begyndelsen af maj, at han intet kender til de biler. Kadyrov tjente angiveligt 131.000 dollar i 2009. En stor Kadyrov-ejendom i landsbyen Tsenteroj, som han stammer fra, ejes af hans mor.

Ifølge 'selvangivelsen' ejer Kadyrovs kone Medina en 209 kvadratmeter lejlighed. To af hans syv børn er medejere, resten for små til at eje noget. Kadyrov samler ikke kun på biler, men også på fine væddeløbsheste. Men - som han har udtalt så tilhører hestene Tjetjenien og ikke ham selv personligt.

Tjetjenerne, som historisk har stået sammen i kampen imod 'russisk imperialisme', står ikke sammen i krigen imod nutidens afart af samme. I det sydlige Tjetjenien, herunder i oprørernes hovedbastioner i bjergene, holder modstanden imod russisk dominans stand, mens tjetjenere i nord er mere parat til eftergivenhed. Det er brudflader, som Moskva kunne udnytte, men det lader man Kadyrov om til hans egen vinding. Men både Kadyrov og centralmagten har forsøgt at hverve religiøse ledere for deres sag.

I et interview til Volgograd udgaven af Argumenty i fakty har Mufti Iljas Khamsat fortalt, at FSB har henvendt sig til ham adskillige gange for at søge hans hjælp imod oprørere, men han svarede: "Som åndelig leder må jeg ikke samarbejde med FSB eller andre sikkerhedsorganer. Så ville jeg miste min autoritet”.
Moskva er også under pres fra udlandet for at skride ind imod Kadyrov, men Moskva har afvist krav fra Dubais regering om udlevering af Kadyrovs fætter, Adam Delimkhanov, medlem af den russiske duma for Putins parti, der er anklaget for at have organiseret mordet på Kadyrovs modstander Salim Jamadajev.

Kadyrovs støtter i Kreml har også været under pres fra en efterforskning i Moskva af et mordforsøg i juni 2009 på Isa Jamadajev, broder til modofferet i Dubai, Salim og til Ruslan Jamadajev, medlem af dumaen, der blev myrdet i Moskva i 2008.

I april 2010 holdt en domstol i Moskva hemmelige høringer om den sag. En video fra høringen endte på forunderlig vis i hænderne på det udsete næste mordoffer, der lækkede den til avisen Moskouskij Komsomoltj. Under afhøring tilstod den anklagede Khavasj Jusupov og sagde, at han var hyret af ingen ringere end Kadyrovs toprådgiver Shaa Turlajev. Jusupov sagde, at Turlajev tog ham med til et møde med Kadyrov, der beordrede drabet.

I april 2010 overdrog politiet i Wien en 214 siders fortrolig rapport til Østrigs anklagemyndighed, hvori Kadyrov og samme Shaa Turlajev beskrives som de hovedskyldige for mordet på Umar Israilov, tidligere livvagt for Kadyrov i Wien i januar 2009.

Ifølge Israilovs enke dukkede Turlajev op i Wien kort før mordet og prøvede uden held at mødes med 
hendes mand. En tjetjensk flygtning, der nu kalder sig Otto Kaltenbrunner, ringede til Turlajev straks efter mordet. Desuden blev en kopi af Turlajevs pas fundet i en flugtbil sammen med en elektronisk flybillet, som han havde brugt til rejsen til Wien.

Human Rights Watch har beskrevet sagen således: "Konklusionen om Ramsan Kadyrov, som den østrigske anklagemyndighed nåede frem til, burde få den russiske regering til endelig at tage de nødvendige skridt til at genetablere lovlige forhold i Tjetjenien".

Det står tilbage at se, om Østrig vil rejse anklage imod Kadyrov. Det står således også tilbage at se, hvad domstolen i Moskva vil gøre med det internationale Kadyrov-problem. Men sagen er, at der foreligger højst miskrediterende beviser og vidnesbyrd om den tjetjenske præsident og hans toprådgiver. Russiske medier, som har taget sagen op, har antydet, at nogle medlemmer af Kremls elite mener, at der skal gribes ind over for Kadyrov.

Spørgsmålet er, om Medvedev kan være på den fløj, for han har dog i modsætning til Putin ytret stor bekymring om de mange uopklarede mord og problemer med menneskerettighederne i Nordkaukasus.

Når det gælder mordet på den tjetjenske menneskeretsadvokat Natalja Estemirova, har Medvedev kaldt det 'indlysende', at hun blev dræbt for sin indsats for menneskerettigheder, og han kondolerede over for hendes familie. Hvor længe kan Moskva ignorere det stigende bjerg af beviser imod Kadyrov?

Ljudmila Aleksejeva, leder af Moscow Helsinki Group, har givet dette svar: "Ramsan Kadyrovs ståen over loven og hans almægtighed afhænger af Putins støtte. Så længe Putin støtter ham, kan ingen krumme så meget som et hår på Kadyrovs hoved, også selv om han dræber os alle sammen".

Men Putin har givet indtryk af irritation over, at Kadyrov har gjort Tjetjenien til den mest selvstændige af samtlige Ruslands regioner, og at han blæser på russisk lovgivning. Måske kan de seneste afsløringer bidrage til at overbevise Putin om, at tiden er inde til exit Kadyrov.

Men om det vil standse voldsspiralen er tvivlsomt, netop fordi det er blevet et nordkaukasisk og ikke kun tjetjensk problem. Og trods efterhånden stor bevidsthed i Kreml om, at der skal økonomisk udvikling til for at løse problemerne, har centralmagten skåret ned på bidragene til Nordkaukasus. Det kan betyde endnu mere vold i fremtiden.

\section{Vibeke Sperling er Østeuropakorrespon- dent på dagbladet Politiken og redaktør af Udenrigs.}

